\title{
ROIS DALAM PENDIDIKAN KARAKTER UMAT
}

\author{
Siti Afifah Adawiyah \\ Universitas Islam Indonesia \\ afiadawiyah@uii.ac.id
}

\begin{abstract}
Character education is still a focus in today's national educational objectives. School is no longer the only part that should transfer character education but also to family and society. These three sections should be synergized to realize character education. If in school is a teacher's assignment, then in society is the task of Rois as a religious leader in his region. With a qualitative approach, data is collected using interview and observation techniques. The results showed that the factors influencing the success of Rois in internalizing the Islamic character of the community are customary or habitual, wills or willpower, descent, and education. Furthermore, in carrying out the role of a religious leader in a region, Rois experienced a change in himself namely the change of Rois' behavior, religious scholarly mastery, and dedication of time and energy.
\end{abstract}

Keywords: character education, Islamic, rois, religious rituals.

\section{Pendahuluan}

Pendidikan karakter menjadi fokus pemerintah yang tertulis dalam undang-undang nomor 20 tahun 2003 tentang Sistem Pendidikan Nasional. Tujuan pendidikan yang tertera dalam undang-undang tersebut merupakan acuan pembentukan karakter manusia yang cerdas, berkepribadian dan berakhlak mulia (Permendikbud, 2003). Sejak tercetusnya undang-undang tersebut hingga saat ini, belum terukur apakah tujuan pendidikan sudah tercapai atau belum. Terlebih perkembangan karakter peserta didik di Indonesia belakangan tidak mencerminkan akhlak mulia sebagaimana yang diharapkan dalam undang-undang. 
Bukti di masyarakat menunjukkan hal yang bertolakbelakang dengan tujuan pendidikan tersebut. Salah satu contoh peserta didik yang menganiaya guru hingga tewas (Candra Setia Budi, 2019) mencerminkan bahwa peserta didik dengan mudah mengabaikan nilai atau norma yang berlaku. Contoh lain tidak berhasilnya pendidikan karakter adalah maraknya kasus perundungan di Indonesia. Berdasarkan data Komisioner Komisi Perlindungan Anak Indonesia (KPAI) pada awal 2019 terdapat 12 kasus kekerasan psikis dan perundungan (Maradewa, 2019). Sedangkan data Komisioner KPAI pada tahun 2018 tercatat sejumlah 107 kasus perundungan dan 127 anak-anak merupakan pelaku perundungan (Dwinanda, 2019). Contoh kasus perundungan adalah video peserta didik melakukan tindakan tidak pantas yaitu merokok dan menantang guru yang tersebar melalui media sosial. Banyak yang menyayangkan tindakan yang dilakukan peserta didik tersebut (Arfah, 2019). Contoh lain yaitu kasus Audrey yang viral dengan tagar JusticeForAudrey pada tahun 2019 hingga Presiden RI juga memberikan pernyataan terkait kasus tersebut (Suciatiningrum, 2019). Kasus tersebut, di luar kontroversial siapa yang benar dan salah, merupakan contoh kasus perundungan yang pelaku ataupun korban adalah anak usia remaja. Kasus yang dipaparkan tersebut memberikan tanda tanya pada tujuan pendidikan yang tertera dalam undang-undang sejak tahun 2003. Realita karakter yang dimiliki peserta didik dengan tujuan pendidikan yang tercantum dalam undang-undang ini bertolak belakang, maka dapat dikatakan bahwa tujuan pendidikan belum tercapai.

Permasalahan pendidikan yang tergambarkan sebelumnya bagaikan rantai yang tidak terputus. Permasalahan tersebut memotret bahwa pendidikan di Indonesia belum sepenuhnya berhasil. Sisi lain dari pendidikan atau hal-hal negatif masih dominan mewarnai pemberitaan pendidikan di Indonesia. Penelitian telah banyak dilakukan untuk menemukan jawaban dalam mengatasi permasalahan karakter tersebut. Seperti yang ditulis oleh Nurhisam dalam artikelnya berjudul Implementasi Pendidikan Karakter sebagai Solusi Dekadensi Moral Anak Bangsa menyampaikan bahwa pendidikan karakter penting untuk ditanamkan dalam diri peserta didik sebagai generasi 
penerus bangsa (Nurhisam, 2017). Selanjutnya Bambang menyatakan bahwa pendidikan karakter merupakan tugas utama orangtua dan guru namun paling penting untuk mengoptimalisasikan pendidikan karakter adalah memberikan contoh atau teladan pada anak (Suryadi, 2015). Pendidikan karakter yang menjadi dasar dalam pengembangan kurikulum 2013 juga telah dilaksanakan berbagai sekolah dan madrasah di Indonesia. Namun, pemberitaan tentang degradasi moral masih menjadi tajuk utama dunia pendidikan.

Pembentukan karakter seyogyanya tidak hanya dilakukan pada peserta didik di sekolah atau madrasah, namun juga di keluarga dan masyarakat. Secara formal, sekolah menjadi salah satu wadah pembentukan karakter. Secara informal, keluarga dan masyarakat menjadi wadah lain yang juga mempengaruhi pembentukan karakter (Kurniawan, 2015). Dari tiga pilar pendidikan tersebut dapat disimpulkan bahwa masyarakat atau lingkungan juga membentuk kepribadian anak. Hal itu menjadi alasan utama mengapa pembentukan karakter tidak hanya dilakukan di sekolah/madrasah tapi juga di lingkungan masyarakat. Oleh karena itu, dalam rangka menjaga lingkungan maka masyarakat pun juga penting untuk dibentuk/diarahkan karakternya.

Dalam pembentukan karakter seseorang, seperti dikutip oleh Khadziq dalam Ibnu Khaldun bahwa peran agama sangat penting karena agama sebagai sumber legitimasi moral dan etika (Khadziq, 2009). Karena sejauh ini, agama-lah yang memiliki batasan-batasan moral dan etika tersebut bukan ilmu pengetahuan. Lebih-lebih transfer ilmu agama dianggap menjadi beban guru agama saja dalam lembaga pendidikan. Guru agama menjadi sorotan pertama ketika permasalahan anak melanggar nilai dan norma yang berlaku. Oleh karena itu transfer pengetahuan dan nilai dalam agama tidak terbatas pada lembaga sekolah atau madrasah, namun juga perlu dilakukan dalam lingkungan sosial atau masyarakat.

Jika sekolah atau madrasah memiliki guru untuk mentransfer ilmu dan nilai tersebut, maka dalam masyarakat ada peran yang juga bertanggungjawab atas transfer ilmu dan nilai agama yaitu rois. Beberapa daerah di Indonesia memiliki konsep rois namun berbeda 
nama seperti ustad di Medan, kyai di Lampung, dan lain sebagainya. Setiap daerah memiliki nama yang berbeda untuk peran seseorang yang bertanggungjawab atas transfer ilmu keagamaan dan implementasinya.

Banyak cara yang dapat dilakukan seorang rois untuk membentuk karakter islami masyarakat. Tugas rois yang diakui masyarakat secara umum adalah mengurus jenazah, mempimpin doa dalam kegiatan ritual keagamaan seperti kenduri dan lain sebagainya, serta membimbing masyarakat untuk melaksanakan ajaran agama Islam. Sebenarnya tugas rois tidak hanya sekedar yang telah disebutkan, tetapi lebih jauh yaitu membentuk karakter masyarakat yang islami di daerah yang ditinggali atau dipimpin oleh rois (Adawiyah, 2018). Dalam mengemban tugas rois, keberhasilan penanaman karakter tidak semudah di sekolah/madrasah. Hal ini dikarenakan tidak ada tenggat waktu sehingga pengukuran keberhasilan menjadi samar dan tidak ada kewajiban tertulis bahwa rois harus membentuk karakter masyarakat. Oleh karena itu, dalam artikel ini akan dibahas lebih jauh tentang faktor yang mempengaruhi penanaman karakter islami di masyarakat dan juga faktor yang secara langsung akan mempengaruhi pribadi rois sebagai seorang pemimpin agama di daerahnya.

Lokasi penelitian yang digunakan adalah Desa Maguwoharjo. Pemilihan lokasi ini karena jumlah rois di Desa Maguwoharjo mencapai 59 orang dan kondisi masyarakatnya heterogen, dimana jumlah penduduk yang beragama Islam dan Kristen dan/atau Katolik berjumlah sama. Dapat dikatakan separuh jumlah penduduknya adalah muslim dan separuh lainnya adalah Kristen dan/atau Katolik. Hal tersebut terbukti dari jumlah gereja yang tidak hanya satu di desa Maguwoharjo. Dengan memilih sampel masyarakat desa Maguwoharjo yang hidup di pinggir kota dengan masyarakat yang heterogen, peran rois tentu memiliki andil besar dalam hal menanamkan nilai-nilai islami di masyarakat Desa Maguwoharjo.

\section{Kerangka Teori}

Pendidikan karakter dalam penelitian ini adalah upaya yang dilakukan dengan pendidikan, pengalaman, habituasi, peraturan, rekayasa lingkungan dan pengorbanan untuk membentuk dan 
menanamkan nilai-nilai dalam peserta didik secara sadar dan bebas yang dipadukan dengan landasan berpikir, sikap dan perilaku yang sudah ada dalam diri peserta didik (Maragustam, 2014). Dapat dikatakan bahwa pendidikan karakter adalah pembentukan tingkah laku dengan metode dan strategi tertentu. Jika subyek dirubah menjadi masyarakat, maka pendidikan karakter yang dimaksud adalah kegiatan penanaman atau internalisasi nilai dalam kegiatan sosial kemasyarakatan. Jika dihubungkan dengan agama sebagai sumber legitimasi maka karakter islami-lah yang ditanamkan dalam masyarakat.

Dalam membentuk karakter, banyak cara yang dapat ditempuh. Sesuai dengan pengertian pendidikan karakter di atas, maka berikut merupakan strategi membentuk manusia berkarakter yaitu (1) Habituasi (pembiasaan) dan pembudayaan yang baik, (2) Membelajarkan hal-hal yang baik (moral knowing), (3) Moral feeling and loving (merasakan dan mencintai yang baik), (4) Moral acting (tindakan yang baik), (5) Keteladanan (moral model) dari lingkungan sekitar, (6) Taubat (kembali) kepada Allah setelah melakukan kesalahan (Maragustam, 2014). Dengan karakter agama dalam diri seseorang, maka karakter tersebut menjadi benteng diri dari pengaruh di luar dirinya. Benteng diri tersebut merupakan nilai-nilai agama, oleh karena itu agama sebagai sumber legitimasi nilai.

Dalam proses pembentukan karakter, tentu terdapat faktor yang mempengaruhi keberhasilannya. Para ahli ilmuwan menggolongkan faktor tersebut menjadi dua bagian yaitu faktor intern dan ekstern. Faktor intern terdiri dari (1) Insting atau Naluri, (2) Adat atau Kebiasaan (Habit), (3) Kehendak atau Kemauan (Iradah), (4) Suara Batin atau Suara Hati, (5) Keturunan (Ahmad, 2004). Kemudian faktor ekstern adalah (1) Pendidikan (Ahmad, 2004) dan (2) Lingkungan (Heri, 2014).

Pembentukan karakter masyarakat adalah hal yang penting dilihat darisudut pandang pelestarian nilai-nilai karakter. Dalam wilayah yang lebih luas, pendidikan karakter adalah salah satu cara melestarikan nilai-nilai keindonesiawian. Dari hal tersebut, maka tanggungjawab dalam melakukan pendidikan karakter tidak hanya terletak pada sekolah saja, namun keluarga dan masyarakat. Suyanta mengatakan bahwa tidak hanya peserta didik yang harus mendapatkan pendidikan 
karakter ini, namun juga orang dewasa. Sehingga tanggungjawab melestarikan dan mewariskan nilai ini menjadi bangunan tingkah laku yang kemudian akan menjadi karakter kolektif (Suyanta, 2013).

Di samping itu, Suyanta mengatakan bahwa pendidikan karakter dapat ditempuh melalui 3 cara yaitu fase pengenalan, penanaman dan pengukuhan dalam kehidupan. Dalam fase pengenalan atau introduksi dijelaskan bahwa dalam pendidikan nonformal pengenalan nilai religious dilakukan melalui kegiatan sosial seperti ceramah, pergaulan keseharian dan sebagainya. Fase selanjutnya adalah penanaman, yaitu proses penghayatan. Dalam fase ini ketiga lingkungan pendidikan dapat bersinergi untuk menanamkan nilai religius yang telah dikenal peserta didik. Terakhir yaitu fase implementasi, dimana peserta didik yang telah paham dan menghayati nilai religius melaksanakan nilai tersebut dalam kesehariannya (Suyanta, 2013).

\section{Metode Penelitian}

Penelitian ini menggunakan pendekatan sosiologi agama karena fokus pada pembentukan karakter masyarakat islami oleh rois atau pemimpin agama. Selanjutnya subjek penelitian dipilih menggunakan metode purposive sampling. Dalam memfasilitasi pengumpulan data, penelitian ini menggunakan metode observasi, wawancara dan dokumentasi. Pola pikir penelitian ini menggunakan pola pikir induktif, yang merupakan pola pikir yang menarik kesimpulan umum dari fakta atau peristiwa khusus yang terjadi di lapangan (Mustofa, 2016). Dalam menganalisis data, penulis menggunakan langkah berikut ini: (1) Meninjau berbagai data yang telah dikumpulkan kemudian data tersebut dibaca, dipelajari dan dipahami, (2) Setelah membaca dan memahami data yang dikumpulkan kemudian mereduksi data, (3) Menyusun data menjadi unit kemudian mengkategorikan (koding), (5) Memeriksa validitas data dengan triangulasi data, (6) Kemudian menafsirkan data menjadi teori substantif sementara (Soegeng, 2017).

\section{Hasil dan Pembahasan}

Ditarik dalam penelitian ini, maka ketiga fase pendidikan karakter dalam masyarakat dapat dijabarkan sebagai berikut. Fase pengenalan, 
rois dengan tugasnya memimpin doa dalam kegiatan tahlilan misalnya, menyampaikan ceramah singkat berupa imbauan kepada warga untuk senantiasa melakukan kebajikan dan menghindari kemungkaran. Ceramah singkat sebelum memimpin doa ini selalu diupayakan oleh rois untuk mengingatkan masyarakat kembali pada syariat agama. Dalam kesempatan lain, rois akan menyampaikan hal yang berbeda namun masih dalam koridor syariat agama Islam. Terlebih, salah satu strategi rois dalam membangun karakter Islami masyarakat adalah dengan memberikan pengantar sebelum melakukan ritual keagamaan (Adawiyah, 2018).

Fase penanaman, dengan pembiasaan yang dilakukan rois dalam menyampaikan syariat agama Islam atau dakwah, merupakan bentuk penanaman pemahaman pada warga. Didukung dengan pendekatan rois secara personal untuk mengarahkan individu kembali ke syariat agama Islam (Adawiyah, 2018), maka fase penanaman karakter dilakukan rois dengan pendekatan berulang-ulang dalam menyampaikan syariat agama Islam baik dalam forum ritual agama ataupun face-to-face dengan individu.

Fase pengukuhan dalam kehidupan, setelah rois membiasakan dakwah dan masyarakat telah menerima pembiasaan tersebut, maka langkah selanjutnya adalah masyarakat atau individu mengimplementasikan apa yang telah dipahaminya terkait syariat agama Islam yang disampaikan rois. Fase ini tentu turut andil rois untuk memberi contoh atau menjadi tauladan bagi warganya (Adawiyah, 2018) juga berpengaruh. Upaya warga dalam menjalankan syariat agama Islam dengan contoh yang nampak adalah melaksanakan sholat berjamaah di masjid dan selalu menghadiri pengajian yang ada dalam rutinitas warga, baik tahlilan atau pengajian di masjid. Nilainilai yang telah dibiasakan oleh rois dalam ceramah dan pendekatan personalnya kemudian dikukuhkan dengan memberikan contoh atau menjadi tauladan bagi warganya, sehingga warga yakin untuk menjalankan nilai tersebut dalam kesehariannya.

Hasil penelitian ini menunjukkan bahwa dalam membentuk karakter masyarakat, rois merupakan peran yang berpengaruh. Peran ini berbeda dengan jabatan struktural dalam sebuah organisasi, rois adalah peran sukarela yang disematkan dalam diri seseorang yang 
dianggap masyarakat memiliki pengetahuan dan pengalaman agama yang dalam dan luas. Peran rois bukan hanya sebagai pembaca doa dalam kegiatan ritual, namun utamanya adalah membimbing masyarakat menjadi muslim yang taat atas perintah Allah (Adawiyah, 2018). Dapat dikatakan bahwa dalam masyarakat yang bertanggunjawab membimbing karakter islami adalah rois.

Dalam melaksanakan peran sebagai rois tentu terdapat hambatan dan tantangan tersendiri. Pada bagian ini akan dijelaskan tentang faktor apa saja yang mempengaruhi pembentukan karakter islami dalam masyarakat. Selanjutnya akan berkaitan erat dengan hal yang mempengaruhi perubahan dalam diri seorang rois. Berikut ini merupakan faktor-faktor yang mempengaruhi pembentukan karakter tersebut, baik yang mendukung maupun yang menghambat.

\section{Adat atau Kebiasaan}

Strategi membentuk karakter manusia yang pertama adalah kebiasaan atau membiasakan hal yang baik (Maragustam, 2014). Oleh karena itu, dalam upaya menggapai karakter islami pada masyarakat diperlukan pembiasaan atas nilai yang ingin dibentuk. Tentu hal tersebut tidak mudah mengingat masyarakat Desa Maguwoharjo heterogen dan sudah memiliki karakter yang dibawa sebelumnya bagi mereka yang merupakan pendatang.

Dalam hal ini, dengan kondisi masyarakat heterogen tersebut, maka ketaatan beragama serta pengetahuan atas agama juga berbeda. Oleh karena itu, hal paling sederhana untuk membiasakan karakter islami adalah membiasakan sholat berjamaah di masjid. Hal tersebut paling mendasar bagi muslim yang taat atas perintah Allah berdasarkan rukun Islam yang kedua yaitu sholat. Untuk membiasakan sholat berjamaah di masjid, maka rois memberikan himbauan secara berkelanjutan kepada masyarakat serta memberi contoh. Himbauan yang dilakukan rois dapat dibagi menjadi dua, yaitu dengan pendekatan personal dan melalui kajian singkat sebelum ritual doa dalam kegiatan kenduri atau selametan. Pendekatan personal dilakukan rois secara langsung kepada individu yang belum melaksanakan sholat berjamaah di masjid. Sedangkan saat 
ritual keagamaan seperti kenduri, maka rois menyampaikan ceramah singkat yang mengajak warga untuk senantiasa menaati perintah dan menjauhi larangan Allah. Waktu tersebut merupakan masa paling tepat dan efisien untuk menyampaikan pesan oleh rois.

Namun tidak cukup hanya memberikan imbauan dan pendekatan personal, namun juga memberikan contoh. Secara tidak langsung, ketika rois selalu melakukan sholat jamaah di masjid, maka warga juga perlahan membangun kebiasaan untuk sholat berjamaah di masjid karena memiliki tokoh untuk dicontoh.

\section{Kehendak atau Kemauan}

Semua hal terkait dengan pembentukan karakter, tentu berpengaruh pada kemauan dalam diri individu. Tidak akan berjalan suatu kegiatan jika seseorang tidak mau menjalankannya. Bahkan menjadi rois pun berdasarkan hasil wawancara, walaupun dia sudah dipilih tetapi tidak mau menerima amanah menjadi rois, maka akan gugur jabatan rois tersebut. Maka kemauan merupakan poin penting dalam hal pembentukan karakter. Keinginan masyarakat digiring untuk menjadi pribadi yang lebih baik itu bergantung kepada diri masing-masing. Jika dilihat dari masyarakat Desa Maguwoharjo, maka tingkat kemauan untuk berubah menjadi pribadi yang lebih baik atau pribadi Islami masih rendah. Dilihat dari hal yang sudah dibiasakan oleh rois sebelumnya, tidak banyak terjadi perubahan pada masyarakat. Tetapi ada beberapa orang yang mau merubah dan menjadi pribadi yang lebih baik lagi.

Contoh di Dusun Karangploso adalah dahulu merupakan lokasi dimana warganya selalu berjudi. Setiap kesempatan hajatan, warga akan melakukan judi. Sampai suatu hari ada salah satu orang yang sering berjudi meninggal, kemudian dalam keadaan duka tersebut tetap melakukan judi. Saat itu rois di Karangploso melakukan perintah untuk berhenti dan memberikan ceramah secara langsung. Sejak saat itu, perilaku judi mulai berkurang dan saat ini sudah tidak ada lagi. Bahkan dusun Karangploso ketika peneliti mengumpulkan data, warga telah berubah menjadi pribadi yang selalu sholat berjamaah di masjid, dibuktikan dengan sholat subuh 3 shaf setiap harinya. 


\section{Keturunan}

Hal ini dapat mendukung dan menghambat sekaligus, bergantung kepada bagaimana latarbelakang orangtua mendidik anaknya. Bahwa seorang anak akan mendapatkan pembelajaran tentang agama Islam dari orangtuanya. Dari hasil observasi, agama yang dianut anak akan mengikuti agama orangtuanya. Namun karakter islami yang tertanam dalam diri anak tidak secara menyeluruh melekat dalam diri anak tersebut, artinya pelaksanaan nilai-nilai agama tidak menyeluruh. Hal ini berbeda dengan seseorang yang baru memeluk agama Islam, justru mua'alaf (orang yang baru masuk Islam) lebih semangat dalam mendalami nilai-nilai agama sehingga ada proses belajar dalam diri yang menunjukkan karakter islami. Berikut merupakan data wawancara dengan salah satu rois dusun Karangploso.

"Itu kelemahan Islam tradisional tadi. Islam keturunan karna orang tuanya dulu juga seperti itu. Jadi lebih mudah mengarahkan Islam mualaf ketimbang Islam tradisional. Yang mualaf itu lebih sregep, otomatis. Kemarin itu di masjid sini ada baiat pengIslaman, April 2016. Mereka belajar sholat itu sejak tahun 2012, jadi mereka belajar sudah 4 tahun menekuni baca qur'ān, bahkan arti arti alqur'ān sudah paham betul, sholatnya sudah faseh lebih faseh, baru masuk Islam. Karena apa, karna mereka menganggap kalau dia masuk Islam itu seperti anak yang sudah lulus ujian, begitu mereka masuk Islam itu mereka sudah lulus, sholat nya bagus ibadah yang lainnya bagus, bacaannya bagus. Sedangkan Islam tradisional keturunan itu kan ya ikutan orangtuanya, orangtuanya Islam ya ikut Islam, mereka ke masjid atau tidak ya ndak tau. Disitu kelemahannya."

\section{Pendidikan}

Tingkat pendidikan di Desa Maguwoharjo yang meningkat juga berpengaruh pada perubahanmasyarakatnya, dimana masyarakattidak lagi menjadikan rois sebagai satu-satunya sumber ilmu keagamaan. Ditandakan dengan bergesernya peran rois menjadi terkesan sekedar pemimpin doa saja. Masyarakat yang sudah mengenyam pendidikan tinggi sudah lebih banyak dan masyarakat tidak mengunggulkan 
rois seperti dulu lagi. Seperti konsultasi permasalahan terkait agama mulai dari masalah waris, mengurus jenazah dan lain-lain, warga akan bertanya kepada rois setempat. Namun belakangan peran rois menjadi terkesan pembaca doa dalam ritual keagamaan saja.

Setiap peran yang dijalani individu tentu memberikan dampak terhadap kehidupan pribadi.Seperti peran rois yang akan mempengaruhi kehidupan sehari-hari rois tersebut. Karena yang telah diketahui bahwa peran rois adalah peran yang disematkan masyarakat kepada seorang individu, maka ada sesuatu yang berubah walaupun hal itu bukanlah perubahan yang besar dalam diri rois. Dalam artikelnya, Shukeri menyampaikan bahwa pemimpin adalah orang yang akan menentukan arah tujuan masyarakat maka pemimpin sangatlah berperan dalam menanamkan nilai religius masyarakat. Disebutkan pula dasar atau syarat seorang menjadi pemimpin yaitu memenuhi syarat kelayakan seorang pemimpin seperti beragama Islam, taat terhadap ajaran Islam, mampu berijtihad dan sebagainya, pemimpin itu dipilih melalui musyawarah, dan pemimpin yang melakukan penyelewengan perlu diluruskan atau diganti. Hal tersebut dijadikan patokan utama karena pemimpin merupakan orang pertama yang akan dijadikan masyarakat sebagai contoh dalam berbagai aspek kehidupan (Mohamad, 2015). Dari peran seorang rois seperti yang telah dijabarkan tersebut, berikut ini merupakan perubahan yang terjadi dalam diri rois.

Pertama yang akan berubah dari dalam diri rois adalah perilaku rois itu sendiri. Setelah menjadi rois, menjadi pemimpin atau tokoh agama yang menjadi sorotan publik tentu secara tidak sadar atau sadarpun rois akan menampakkan perilaku terbaiknya. Walaupun perilaku sebelumnya bukanlah perilaku yang buruk, namun rois lebih menjaga perilaku baik diri maupun keluarga. Dalam hasil wawancara, narasumber menyampaikan bahwa seorang rois menjadi sorotan masyarakat sehingga berusaha menunjukkan tingkah laku yang sesuai dengan ajaran agama Islam. Dalam kesempatan lain, narasumber lain juga menyampaikan bahwa yang berubah sampai mengurangi kegiatan yang terdapat bercandaan didalamnya. Hal ini menunjukkan bahwa menjadi seorang rois akan berusaha menjaga tingkah laku dan ucapan karena menjadi tokoh atau sorotan. 
Kedua menjadi rois dituntut untuk terus memperdalam pengetahuan keagamaan. Hal ini disebabkan oleh tanggungjawab seorang rois dalam memimpin bidang keagamaan di masyarakat, sehingga masyarakat akan menjadikan rois sebagai tumpuan dalam memutuskan perkara keagamaan. Dalam hal memutuskan tersebut, seorang rois harus memiliki wawasan yang luas sehingga rois perlu terus belajar agama. Seorang rois mendapat pembelajaran dan pengalaman dari peran yang diembannya, dari kejadian yang dihadapi, dan dari perbedaan pemahaman dalam beragama tentu memberikan perspektif baru kepada rois. Dengan keadaan tersebut akan mendesak rois untuk mencari tahu jawaban terbaik dari masalah yang ada dengan memperdalam pengetahuannya. Menjadi rois pun memberikan ilmu secara langsung kepada rois karena dijadikan pemuka agama. Tentu dalam keadaan tersebut rois harus mampu membimbing masyarakatnya menjadi pribadi Islami atau individu yang menjalankan syariat agama Islam. Dengan mengetahui lebih banyak ilmu agama, maka rois akan mampu membimbing atau membina keagamaan masyarakat di daerahnya. Dalam menambah ilmu keagamaan ini dibantu oleh Kantor Urusan Agama (KUA) setempat, diadakan pelatihan bagi rois di Desa Maguwoharjo terkait hal keagamaan salah satunya mengurus jenazah atau tata cara masuk Islam. Selain itu, rois memperluas pengetahuan agamanya dengan membaca buku referensi.

Ketiga seorang rois mendedikasikan tenaga dan waktunya untuk melayani masyarakat. Pengorbanan rois cukup besar untuk hal tersebut, karena kebutuhan masyarakat tidak tentu dan tidak kenal waktu. Seperti seorang rois diminta untuk memandikan jenazah pada pukul dua pagi, dimana waktu itu adalah waktu untuk istirahat. Dalam kesempatan lain, narasumber menyampaikan bahwa sampai ijin ketika bekerja di kantor dan pulang untuk melakukan salah satu tugas rois yaitu mengurus jenazah.

Dari ketiga peran tersebut dapat disimpulkan bahwa menjadi seorang rois adalah pekerjaan non-formal yang memberikan manfaat sekaligus harus berkorban. 


\section{Kesimpulan}

Pendidikan karakter dapat tercapai melalui sinergi antara sekolah, keluarga dan masyarakat. Pendidikan karakter islami yang berlangsung di masyarakat dipengaruhi oleh adat atau kebiasaan, kehendak atau kemauan, keturunan, dan pendidikan. Pendidikan karakter islami yang terjadi di masyarakat menjadi tanggungjawab rois. Dalam melaksanakan tugasnya, rois mengalami perubahan dalam hidupnya dalam hal perilaku, penguasaan keilmuan agama, dan dedikasi waktu serta tenaga.

\section{Daftar Pustaka}

Arfah, H. (2019). Reaksi Kadis Pendidikan Gresik soal Kasus Siswa Merokok dan Tantang Guru. Retrieved from https://regional.kompas.com/ $\mathrm{read} / 2019 / 02 / 11 / 08353221 /$ reaksi-kadis-pendidikan-gresiksoal-kasus-siswa-merokok-dan-tantang-guru

Adawiyah, S. I. (2018). The Influence of Rois as an Agent of Religious Rituals. Presented paper in The $2^{\text {nd }}$ SEA-AFSID "Fostering Sustainable Development in Southeast Asia: New Challenges, Perspectives, and Strategies.

Budi, C. S. "Fakta di Balik Kasus Guru SMK yang Tewas Ditikam Siswanya, Sekolah Kumpulan Murid Bermasalah". Artikel dalam https://manado.kompas.com/read/2019/10/29/05150001/ fakta-di-balik-kasus-guru-smk-yang-tewas-ditikam-siswanyasekolah-kumpulan?page $=$ all.

Dwinanda, R. (2019). KPAI: Angka Perundungan di Lingkungan Sekolah Masih Tinggi.

Gunawan, H. 2014. Pendidikan Karakter: Konsep dan Implementasi. cet. ke-3. Bandung: Alfabeta.

Khadziq. (2009). Islam dan Budaya Lokal: Belajar Memahami Realitas Agama dalam Masyarakat. Yogyakarta: Teras.

Kurniawan, M. I. (2015). Tri Pusat Pendidikan Sebagai Sarana Pendidikan Karakter Anak Sekolah Dasar. PEDAGOGIA: Jurnal Pendidikan, 4(1), 41. https://doi.org/10.21070/pedagogia.v4i1.71 Lakonawa, P. (2013). Agama dan Pembentukan Cara Pandang Serta Perilaku Hidup Masyarakat. Humaniora, Vol.4, No.2, 790-799. 


\section{eL-Tarbawj siti Affah Adawiyah}

Maradewa, R. (2019). Catatan KPAI di Hardiknas: Kasus Anak Bully Guru Meningkat Drastis. Retrieved from https://www.kpai. go.id/berita/catatan-kpai-di-hardiknas-kasus-anak-bully-gurumeningkat-drastis

Mohamad, S. (2015). Pembentukan Masyarakat Berakhlak Mengikut Politik Islam. Jurnal Usuluddin, Volume 8(Issue 8), 145-174.

Mustofa, I. (2016). Jendela Logika dalam Berfikir: Deduksi dan Induksi sebagai Dasar Penalaran Ilmiah. EL-BANAT: Jurnal Pemikiran Dan Pendidikan Islam, 6(2), 122-142. https://doi.org/10.1093/ jhered/es1028

Nurhisam, Luqman. (2017). Implementasi Pendidikan Karakter sebagai Solusi Dekadensi Moral Anak Bangsa. Elementary, Vol.5, No.1, 110-131.

Suciatiningrum, D. (2019). Miris, Ini 7 Fakta dalam Kasus Pengeroyokan Audrey. Retrieved from https://www.idntimes.com/news/ indonesia/dini-suciatiningrum/miris-ini-7-fakta-dalam-kasuspengeroyokan-audrey/full

Suryadi, Bambang. (2015). Pendidikan Karakter: Solusi Mengatasi Krisis Moral Bangsa. Nizham, Vol.4, No.2, 71-84.

Suyanta, S. (2013). Membangun Pendidikan Karakter Dalam Masyarakat. Jurnal Ilmiah Islam Futura, 13(1), 1. https://doi. org/10.22373/jiif.v13i1.568 